\title{
Association of the solute carrier family 11 member 1 gene polymorphisms with susceptibility to leprosy in a Brazilian sample
}

\author{
Maria José Franco Brochado', Maria Fernanda Chociay Gatti', \\ Marco Antônio Zago ${ }^{2,3}$, Ana Maria Roselino ${ }^{1 /+}$

\begin{abstract}
¿Universidade de São Paulo, Faculdade de Medicina de Ribeirão Preto, Hospital Universitário, Departamento de Clínica Médica, Divisão de Dermatologia, Ribeirão Preto, SP, Brasil ${ }^{2}$ Universidade de São Paulo, Faculdade de Medicina de Ribeirão Preto, Hospital Universitário, Departamento de Clínica Médica, Divisão de Hematologia, Ribeirão Preto, SP, Brasil

${ }^{3}$ Universidade de São Paulo, Faculdade de Medicina de Ribeirão Preto, Centro de Terapia Celular, Ribeirão Preto, SP, Brasil
\end{abstract}

\begin{abstract}
Natural resistance-associated macrophage protein 1/solute carrier family 11 member 1 gene (Nramp1/Slc11a1) is a gene that controls the susceptibility of inbred mice to intracellular pathogens. Polymorphisms in the human Slc11a1/Nrampl gene have been associated with host susceptibility to leprosy. This study has evaluated nine polymorphisms of the Slc11a1/Nramp1 gene [(GT)n, 274C/T, 469+14G/C, 577-18G/A, 823C/T, 1029 C/T, 1465-85G/A, 1703G/A, and 1729+55del4] in 86 leprosy patients (67 and 19 patients had the multibacillary and the paucibacillary clinical forms of the disease, respectively), and 239 healthy controls matched by age, gender, and ethnicity. The frequency of allele 2 of the (GT)n polymorphism was higher in leprosy patients $[p=0.04$, odds ratio $(O R)=1.49]$, whereas the frequency of allele 3 was higher in the control group $(p=0.03$; OR $=0.66)$. Patients carrying the 274T allele ( $p$ $=0.04 ; \mathrm{OR}=1.49)$ and TT homozygosis $(p=0.02 ; \mathrm{OR}=2.46)$, such as the 469+14C allele $(p=0.03 ; \mathrm{OR}=1.53)$ of the 274C/T and 469+14G/C polymorphisms, respectively, were more frequent in the leprosy group. The leprosy and control groups had similar frequency of the 577-18G/A, 823C/T,1029C/T,1465-85G/A, 1703G/A, and 1729+55del4 polymorphisms. The 274C/T polymorphism in exon 3 and the $469+14 G / C$ polymorphism in intron 4 were associated with susceptibility to leprosy, while the allele 2 and 3 of the (GT)n polymorphism in the promoter region were associated with susceptibility and protection to leprosy, respectively.
\end{abstract}

Key words: Slc11a1/Nramp1 - leprosy - polymorphism

Leprosy is a chronic granulomatous infection affecting the skin and peripheral nerves; it is caused by the obligate intracellular bacillus Mycobacterium leprae (Walker \& Lockwood 2007). The disease is characterised by a spectrum of clinical manifestations - from the tuberculoid (TT) to the lepromatous (LL) poles - which correlate with the host cell-mediated immunity against the bacillus. In patients with TT leprosy or the paucibacillary (PB) clinical form of the disease, the M. leprae-specific T-helper (Th)1-type immunity is robust, which limits the clinical disease. Only a few bacilli appear in skin biopsy lesions. LL leprosy or the multibacillary (MB) clinical form of the disease is characterised by low cell-mediated immunity with a humoral Th2 response. The patients display disseminated infection and high bacillary load in

doi: 10.1590/0074-02760150326

Financial support: CAPES, CNPq, FAPESP, FAEPA

Results were partially published in MJF Brochado, NA de Paula, AM Roselino. Leprosy: from clinical diagnosis to benchwork. In Leprosy: epidemiology, treatment strategies, and current research challenges, RS Kopp (Ed), Nova Science Publishers, Inc, Hauppauge, 90 pp.

+ Corresponding author: amfrosel@fmrp.usp.br

Received 26 August 2015

Accepted 2 December 2015 skin biopsy lesions. In-between these two polar forms, unstable borderline (BB) cases with specific clinical, immunological, and pathological characteristics exist (Ridley \& Jopling 1966). Besides environmental and lifestyle factors, host genetic susceptibility has been attributed to the clinical diversity of the disease (Misch et al. 2010).

The solute carrier family 11 member 1 gene (Slcllal), also known as natural resistance-associated macrophage protein 1 (Nrampl), is a gene that controls the susceptibility of inbred mice to intracellular pathogens, including Mycobacterium, Salmonella, and Leishmania microorganisms (Vidal et al. 1993). In inbred laboratory mice, susceptibility to infection originates from a single nonconservative glycine-to-aspartic acid substitution at position 169 within the transmembrane domain 4 of the Slclla1/Nrampl gene (Malo et al. 1994, Vidal et al. 1996). Functionally, murine NRAMP proteins influence pathogen viability and/or replication within macrophages by transporting iron and other divalent cations across the phagosomal membrane (Gruenheid \& Gros 2000).

The human homologue Slc1lal/Nrampl gene has been cloned and sequenced. This gene is located in the human chromosome region $2 \mathrm{q} 35$. It consists of 15 exons encoding a protein of 550 amino acids that exhibits $85 \%$ identity ( $92 \%$ similarity) with murine Nramp1 (Cellier et al. 1994, Blackwell et al. 1995). In addition, a microsatellite variant located in the immediate 5 ' region of the gene, four variants in the coding region, three variants in introns, and one variant located in the 3'untranslated region (UTR) of the Slc1lal/Nrampl gene have been de- 
scribed, but the functional significance of these variants remains uncertain (Liu et al. 1995). Studies on the human homologue Slc1lal/Nrampl have linked/associated the region/gene with leprosy phenotypes (Abel et al. 1995, Meisner et al. 2001, Hatta et al. 2010). A meta-analysis study has confirmed the association of Slc1lal/Nramp1 gene polymorphisms with susceptibility to tuberculosis (Li et al. 2011). In this regard, a population-based association study in Brazil has shown that lepromin-negative individuals harbouring specific genotypes of a (GT)n promoter repeat of the Slcllal/Nrampl gene are at risk of developing leprosy, suggesting an interplay between genetic and immunological factors (Ferreira et al. 2004).

In the present case-control study, we have evaluated the association of nine polymorphisms [(GT)n, 274C/T, 469+14G/C, 577-18G/A, 823C/T, 1029 C/T, 1465-85G/A, $1703 \mathrm{G} / \mathrm{A}$, and 1729+55del4] of the Nrampl/Slcllal gene with susceptibility to leprosy or the clinical forms of leprosy.

\section{SUBJECTS, MATERIALS AND METHODS}

Subjects - Eighty-six patients with leprosy from the leprosy outpatients unit of the University Hospital of the Ribeirão Preto Medical School, University of São Paulo, São Paulo, Brazil were recruited from 2002-2006. Leprosy classification was based on clinical and histological criteria (Ridley \& Jopling 1966). Besides dermatological and neurological exams, lymph smear bacilloscopy, skin biopsy, Mitsuda test, and serology for anti-PGL1 were used.

Sixty-seven patients were classified as having MB leprosy [ 15 females (mean age $=38 \pm 17$ years) and 52 males (mean age $=49 \pm 15$ years)], which included nine, seven, 16 , and 35 patients with the mid-BB, borderlinetuberculoid (BT), borderline-lepromatous, and LL clinical forms, respectively. Nineteen patients classified with PB leprosy [ 8 females (mean age $=45 \pm 21$ years) and 11 males (mean age $=49 \pm 18$ years)], which included 13 and six patients with the TT and BT clinical forms, respectively, were also included in this study. All the 239 healthy controls were blood donors affiliated with the Blood Bank of the University Hospital of Ribeirão Preto Medical School. The patients and controls were from the same region and were matched by age, gender, and skin colour. All the subjects provided an informed consent as required by the Institutional Ethical Committee of the University Hospital of Ribeirão Preto Medical School.

Slc1la1/Nrampl genotyping - DNA was isolated from peripheral blood leukocytes by the salting-out method (Miller et al. 1988). A total of $100 \mathrm{ng}$ of genomic DNA were amplified in $25 \mu \mathrm{L}$ (final volume) of a reaction mixture containing $1 \mathrm{x}$ reaction buffer $(20$ $\mathrm{mM}$ Tris $\mathrm{HCl} \mathrm{pH} 8.4,50 \mathrm{mM} \mathrm{KCl}, 1.5 \mathrm{mM} \mathrm{MgCl}_{2}$, and $0.01 \% \mathrm{BSA}), 10 \mathrm{mM}$ dNTP, $2.5 \mathrm{mM}$ of each primer, and 1.0 U Taq polymerase (Invitrogen, USA). The Slcllal/ Nramp1 gene polymorphisms [(GT)n (rs34448891), 274C/T (rs2276631), 469+14G/C (rs3731865), 57718G/A (rs3731864), 823C/T (rs17221959), 1029C/T (rs201565523), 1465-85G/A (rs2279015), 1703G/A (rs17235409), and 1729+55del4 (rs17235416)] were detected through polymerase chain reaction (PCR) followed by enzymatic restriction, according to protocols described by Liu et al. (1995), Singal et al. (2000), and Graham et al. (2000), with some modifications.
Statistical analysis - Genotype and allele frequencies were analysed by Fisher's exact test. Logistic regression analyses were employed to assess the association between these polymorphisms and the disease. The HardyWeinberg equilibrium (HWE) was analysed by using the Genepop 4.2 software. The level of significance was set at $p \leq 0.05$ in all the analyses. Data were analysed with the aid of the Statistical Analyses System software v.9.3 (SAS Institute, USA).

\section{RESULTS}

Table I lists the distribution of the frequency of the (GT)n, 274C/T, and 469+14G/C Slclla1/Nramp1 gene polymorphisms in patients with leprosy and control subjects as well as the association tests of these polymorphisms for the different spectra of leprosy. Regarding the (GT)n polymorphism, the frequency of allele 2 in leprosy patients was higher as compared with the control group $[32 \%$ vs. $24 \% ; \mathrm{p}=0.04$, odds ratio $(\mathrm{OR})=1.49,95 \%$ confidence interval $(\mathrm{CI})=1.02-2.18]$; the frequency of allele 3 was higher in the control group ( $74 \%$ vs. $65 \%$; $=0.03$; $\mathrm{OR}=0.66,95 \% \mathrm{CI}=0.45-0.96$ ). Analysis of the $274 \mathrm{C} / \mathrm{T}$ polymorphism revealed increased frequency of the $274 \mathrm{~T}$ allele $(33 \%$ vs. $24 \%, \mathrm{p}=0.04 ; \mathrm{OR}=1.49,95 \% \mathrm{CI}=1.02$ $2.18)$ and the $\mathrm{T} / \mathrm{T}$ genotype $(14 \%$ vs. $7 \%, \mathrm{p}=0.02 ; \mathrm{OR}=$ $2.46,95 \% \mathrm{CI}=1.08-5.62$ ) among leprosy patients as compared with the control group. Similarly, a significantly higher frequency of the $469+14 \mathrm{C}$ allele of the $469+14 \mathrm{G} / \mathrm{C}$ polymorphism occurred in leprosy patients as compared with the controls ( $30 \%$ vs. $23 \%, \mathrm{p}=0.03$; OR $=1.53,95 \%$ $\mathrm{CI}=1.03-2.25$ ). From a statistical viewpoint, the leprosy and control groups did not differ in terms of the genotypic and allelic frequencies of the Slcllal/Nrampl 823C/T, 1465-85G/A, $1703 \mathrm{G} / \mathrm{A}$, and 1729+55del4 polymorphisms (Table II). Regarding the 577-18G/A and 1029C/T polymorphisms, all the participants showed the genotypes "GG" and "CC", respectively (data not shown). None of the nine polymorphisms of the Slcllal/Nrampl gene was significantly different among the clinical forms of leprosy. The genotype distributions in the control group agreed with the HWE for all the polymorphisms.

\section{DISCUSSION}

Positive and negative associations of the Nrampl/Slcllal gene polymorphisms with leprosy have been described (Roy et al. 1999, Fitness et al. 2004, Hatta et al. 2010).

This case-control study revealed that the promoter microsatellite (GT)n and the $274 \mathrm{C} / \mathrm{T}$ and $469+14 \mathrm{G} / \mathrm{C}$ polymorphisms of the Slc1lal/Nrampl gene are associated with leprosy.

The microsatellite (GT)n repeat in the promoter region of the Slcllal/Nrampl gene is functional during transcription regulation (Blackwell et al. 1995, Searle \& Blackwell 1999, Bayele et al. 2007). Nine variants have been described at this site (Blackwell et al. 1995, Graham et al. 2000, Kojima et al. 2001, Zaahl et al. 2004). In reporter gene studies, Searle and Blackwell (1999) have shown that these four alleles differ in their ability to drive gene expression. Allele 3 at the GTn polymorphism drives higher expression of the Slc1lal/Nrampl gene, whilst allele 2 drives lower Slcllal/Nramp1 expression in the presence of bacterial lipopolysaccharide. 
TABLE I

Allelic and genotypic frequencies of the natural resistance-associated macrophage protein 1/solute carrier family 11 member 1 gene polymorphisms in leprosy and control groups

\begin{tabular}{|c|c|c|c|c|c|}
\hline Polymorphism site & $\begin{array}{c}\text { Alleles/ } \\
\text { genotypes }\end{array}$ & $\begin{array}{c}\text { Leprosy } \\
\mathrm{n}=86 \\
\mathrm{n}(\%)\end{array}$ & $\begin{array}{c}\mathrm{MB} \\
\mathrm{n}=67 \\
\mathrm{n}(\%)\end{array}$ & $\begin{array}{c}\text { PB } \\
n=19 \\
n(\%)\end{array}$ & $\begin{array}{c}\text { Controls } \\
\mathrm{n}=239 \\
\mathrm{n}(\%)\end{array}$ \\
\hline Promoter microsatellite & Allele & & & & \\
\hline \multirow[t]{12}{*}{ (GT)n repeat } & 1 & $1(0.5)$ & $1(0.5)$ & $0(0)$ & $4(1)$ \\
\hline & 2 & $56(32.5)$ & $43(32)$ & $13(34)$ & $117(24)^{d}$ \\
\hline & 3 & $112(65)$ & $88(66)$ & $24(63)$ & $353(74)^{b}$ \\
\hline & 5 & $3(2)$ & $2(1.5)$ & $1(3)$ & $4(1)$ \\
\hline & Genotype & & & & \\
\hline & 12 & $0(0)$ & $0(0)$ & $0(0)$ & $1(0.5)$ \\
\hline & 13 & $1(1)$ & $1(1.5)$ & $0(0)$ & $3(1)$ \\
\hline & 22 & $13(15)$ & $11(16.5)$ & $2(11)$ & $16(7)$ \\
\hline & 23 & $28(33)$ & $20(30)$ & $8(42)$ & $83(35)$ \\
\hline & 25 & $2(2)$ & $1(1.5)$ & $1(5)$ & $1(0.5)$ \\
\hline & 33 & $41(48)$ & $33(49)$ & $8(42)$ & $132(55)$ \\
\hline & 35 & $1(1)$ & $1(1.5)$ & $0(0)$ & $3(1)$ \\
\hline Exon 3 & Allele & & & & \\
\hline \multirow[t]{6}{*}{$274 \mathrm{C} / \mathrm{T}$} & $\mathrm{C}$ & $116(67)$ & $92(68)$ & $24(63)$ & $361(76)$ \\
\hline & $\mathrm{T}$ & $56(33)$ & $42(32)$ & $14(37)$ & $117(24)^{c}$ \\
\hline & Genotype & & & & \\
\hline & $\mathrm{CC}$ & $42(49)$ & $34(51)$ & $8(42)$ & $138(58)$ \\
\hline & CT & $32(37)$ & $24(36)$ & $8(42)$ & $85(35)$ \\
\hline & TT & $12(14)$ & $9(13)$ & $3(16)$ & $16(7)^{d}$ \\
\hline Intron 4 & Allele & & & & \\
\hline \multirow[t]{6}{*}{$469+14 \mathrm{G} / \mathrm{C}$} & $\mathrm{C}$ & $53(30)$ & $40(30)$ & $13(34)$ & $108(23)^{c}$ \\
\hline & G & $119(70)$ & $94(70)$ & $25(66)$ & $370(77)$ \\
\hline & Genotype & & & & \\
\hline & $\mathrm{CC}$ & $10(12)$ & $8(12)$ & $2(11)$ & $14(6)$ \\
\hline & CG & $33(38)$ & $24(36)$ & $9(47)$ & $80(33)$ \\
\hline & GG & $43(50)$ & $35(52)$ & $8(42)$ & $145(61)$ \\
\hline
\end{tabular}

$a$ : allele $2[\mathrm{p}=0.04$, odds ratio $(\mathrm{OR})=1.49,95 \%$ confidence interval $(\mathrm{CI})=1.02-2.18] ; b$ : allele $3(\mathrm{p}=0.03 ; \mathrm{OR}=0.66,95 \% \mathrm{CI}=$ $0.45-0.96) ; c: 274 \mathrm{~T}$ allele $(\mathrm{p}=0.04 ; \mathrm{OR}=1.49,95 \% \mathrm{CI}=1.02-2.18) ; d$ : TT genotype $(\mathrm{p}=0.02 ; \mathrm{OR}=2.46,95 \% \mathrm{CI}=1.08-5.62)$; $e: 469+14 \mathrm{C}$ allele $(\mathrm{p}=0.03 ; \mathrm{OR}=1.53,95 \% \mathrm{CI}=1.03-2.25)$; MB: multibacillary; PB: paucibacillary.

These authors suggested that the higher expression of allele 3 should drive pro-inflammatory activated macrophage responses that are functionally linked to susceptibility to autoimmune disease. On the other hand, the lower level of Slc11al/Nrampl expression promoted by allele 2 should contribute to susceptibility to infectious disease (Searle \& Blackwell 1999, Blackwell et al. 2003). In our study, we have observed that the frequency of allele 2 of the promoter microsatellite (GT)n of the Slcllal/Nrampl gene is higher in the leprosy group, which suggests its association with susceptibility to leprosy. In line with our results, Ferreira et al. (2004) verified that individuals with a negative lepromin response associated with genotypes " 22 " and " 23 " presented greater risk of developing leprosy. In contrast to our study, a candidate gene study in a population from northern Malawi (Fitness et al. 2004)and India (Roy et al. 1999) showed no association of the microsatellite (GT)n repeat in the promoter region of the Slcllal/Nrampl gene with leprosy.

Here, we have found that two other single nucleotide changes in exon $3(274 \mathrm{C} / \mathrm{T})$ and intron $4(469+14 \mathrm{G} / \mathrm{C})$ of the Slc1la1/Nrampl gene are associated with susceptibility to leprosy. Leprosy patients carry the $274 \mathrm{~T}$ allele and TT homozygosis of the $274 \mathrm{C} / \mathrm{T}$ polymorphism and the $469+14 \mathrm{C}$ allele of the $469+14 \mathrm{G} / \mathrm{C}$ polymorphism more frequently than the controls. These results may help to prevent the leprosy disease by screening for the $274 \mathrm{C} / \mathrm{T}$ and $469+14 \mathrm{G} / \mathrm{C}$ polymorphisms in healthy contacts. To our knowledge, there are few reports about the $274 \mathrm{C} / \mathrm{T}$ variation of the Slcllal/Nrampl gene in leprosy. 
TABLE II

Allelic and genotypic frequencies of the natural resistance-associated macrophage protein 1/solute carrier family 11 member 1 gene polymorphisms in leprosy and control groups

\begin{tabular}{|c|c|c|c|c|c|}
\hline $\begin{array}{l}\text { Polymorphism } \\
\text { site }\end{array}$ & $\begin{array}{l}\text { Alleles/ } \\
\text { genotypes }\end{array}$ & $\begin{array}{c}\text { Leprosy } \\
\mathrm{n}=86 \\
\mathrm{n}(\%)\end{array}$ & $\begin{array}{c}\mathrm{MB} \\
\mathrm{n}=67 \\
\mathrm{n}(\%)\end{array}$ & $\begin{array}{c}\text { PB } \\
n=19 \\
n(\%)\end{array}$ & $\begin{array}{c}\text { Controls } \\
\mathrm{n}=239 \\
\mathrm{n}(\%)\end{array}$ \\
\hline Exon 8 & Allele & & & & \\
\hline \multirow[t]{6}{*}{$823 \mathrm{C} / \mathrm{T}$} & $\mathrm{C}$ & $152(88)$ & $119(88)$ & $33(86)$ & $430(89)$ \\
\hline & $\mathrm{T}$ & $20(12)$ & $15(12)$ & $5(14)$ & $48(11)$ \\
\hline & Genotype & & & & \\
\hline & $\mathrm{CC}$ & $69(80)$ & $54(81)$ & $15(79)$ & $195(81)$ \\
\hline & $\mathrm{CT}$ & $14(16)$ & $11(16)$ & $3(16)$ & $40(17)$ \\
\hline & $\mathrm{TT}$ & $3(4)$ & $2(3)$ & $1(5)$ & $4(2)$ \\
\hline Intron 13 & Allele & & & & \\
\hline \multirow[t]{6}{*}{$1465-85 \mathrm{G} / \mathrm{A}$} & G & $81(47)$ & $63(47)$ & $18(47)$ & $256(54)$ \\
\hline & A & $91(53)$ & $71(53)$ & $20(53)$ & $222(46)$ \\
\hline & Genotype & & & & \\
\hline & GG & $22(26)$ & $16(24)$ & $6(31)$ & 79 (33) \\
\hline & GA & $37(43)$ & $31(46)$ & $6(31)$ & $98(41)$ \\
\hline & AA & $27(31)$ & $20(30)$ & $7(38)$ & $62(26)$ \\
\hline Exon 15 & Allele & & & & \\
\hline \multirow[t]{5}{*}{$1703 \mathrm{G} / \mathrm{A}$} & G & $168(97)$ & $131(98)$ & 37 (99) & $462(96)$ \\
\hline & A & $4(3)$ & $3(2)$ & $1(1)$ & $16(4)$ \\
\hline & Genotype & & & & \\
\hline & GA & $4(5)$ & $3(4)$ & $1(5)$ & $16(7)$ \\
\hline & GG & $82(95)$ & $64(96)$ & $18(95)$ & $223(93)$ \\
\hline 3' UTR & Allele & & & & \\
\hline \multirow[t]{6}{*}{$1729+55$ del 4} & +TGTG & $161(94)$ & $125(93)$ & $36(95)$ & $440(92)$ \\
\hline & -TGTG & $11(6)$ & $9(7)$ & $2(5)$ & $38(8)$ \\
\hline & Genotype & & & & \\
\hline & +TGTG & $76(88)$ & $59(88)$ & 17 (89) & $204(85)$ \\
\hline & +TGTG/-TGTG & $9(10)$ & $7(10)$ & $2(11)$ & $32(13)$ \\
\hline & -TGTG & $1(2)$ & $1(2)$ & $0(0)$ & $3(2)$ \\
\hline
\end{tabular}

MB: multibacillary; PB: paucibacillary; UTR: untranslated region.

Recently, a Brazilian study of 201 leprosy cases revealed that the presence of the homozygosis mutant "TT" was related to risk for type 2 reaction (Teixeira et al. 2010). Regarding the $469+14 \mathrm{G} / \mathrm{C}$ polymorphisms, Hatta et al. (2010) evaluated three variants of the Nrampl/Slcllal gene $(1703 \mathrm{G} / \mathrm{A}, 1729+55 \mathrm{del} 4$, and $469+14 \mathrm{G} / \mathrm{C})$ an $\mathrm{d}$ found that the "GC" heterozygosis of the $469+14 \mathrm{G} / \mathrm{C}$ polymorphism was associated with leprosy per se and with PB leprosy in patients from Indonesia. In contrast to our result, several reports have not detected any association of the $469+14 \mathrm{G} / \mathrm{C}$ polymorphism with leprosy (Roy et al. 1999, Meisner et al. 2001, Vejbaesya et al. 2007). The physiological effect of these polymorphisms of the Nrampl/Slcllal gene is not fully understood.

We have also evaluated six $(577-18 \mathrm{G} / \mathrm{A}, 823 \mathrm{C} / \mathrm{T}$, $1029 \mathrm{C} / \mathrm{T}, 1465-85 \mathrm{G} / \mathrm{A}, 1703 \mathrm{G} / \mathrm{A}$, and $1729+55 \mathrm{del} 4)$ other Slc1lal/Nrampl gene polymorphisms, but we have not found any association with leprosy. In a case- control study in Mali, the 3' UTR $(1729+55$ del4) polymorphisms were specifically associated with MB leprosy, but not with leprosy per se (Meisner et al. 2001). However, candidate gene studies in a population from northern Malawi (Fitness et al. 2004), India (Roy et al. 1999), and Thailand (Vejbaesya et al. 2007) failed to detect any association between Nrampl/Slc11al polymorphisms and leprosy.

Discrepancies exist in the polymorphisms of the Slcllal/Nrampl gene associated with leprosy, and the functional significance of these polymorphisms remains unclear. In the mouse model, the Slc1la1/Nrampl alleles influence the intrinsic ability of macrophages to resist infection by intracellular parasites (Skamene 1994). Other studies have shown that the Slcllal/Nrampl locus encodes a protein that also exerts pleiotropic effects, including regulation of the Th1/Th2 balance of the adaptive immune response to infection (Soo et al. 1998, 
Blackwell et al. 2000). It is very important to identify the genetic factors that regulate the Th1/Th2 balance in response to foreign antigens. The polymorphisms of the Slc1la1/Nrampl gene could play an important role in the immune response against $M$. leprae.

In conclusion, our results have demonstrated that the $274 \mathrm{C} / \mathrm{T}$ polymorphism in exon 3 and the $469+14 \mathrm{G} / \mathrm{C}$ polymorphism in intron 4 of the Slcllal/Nrampl gene are associated with susceptibility to leprosy. Furthermore, the (GT)n polymorphisms in the promoter region of the Slc1lal/Nrampl gene are associated with protection or susceptibility to leprosy.

\section{REFERENCES}

Abel L, Vu DL, Oberti J, Nguyen VT, Van VC, Guilloud-Bataille M, Schurr E, Lagrange PH 1995. Complex segregation analysis of leprosy in southern Vietnam. Genet Epidemiol 12: 63-82.

Bayele HK, Peyssonnaux C, Giatromanolaki A, Arrais-Silva WW, Mohamed HS, Collins H, Giorgio S, Koukourakis M, Johnson RS, Blackwell JM, Nizet V, Srai SK 2007. HIF-1 regulates heritable variation and allele expression phenotypes of the macrophage immune response gene $S L C 11 A 1$ from a Z-DNA forming microsatellite. Blood 110: 3039-3048.

Blackwell JM, Barton CH, White JK, Searle S, Baker AM, Williams H, Shaw MA 1995. Genomic organization and sequence of the human NRAMP gene: identification and mapping of a promoter region polymorphism. Mol Med 1: 194-205.

Blackwell JM, Searle S, Goswami T, Miller EN 2000. Understanding the multiple functions of Nramp1. Microbes Infect 2: 317-321.

Blackwell JM, Searle S, Mohamed H, White JK 2003. Divalent cation transport and susceptibility to infectious and autoimmune disease: continuation of the $\mathrm{Ity} / \mathrm{Lsh} / \mathrm{Bcg} / \mathrm{Nrampl} / \mathrm{Slcllal}$ gene story. Immunol Lett 85: 197-203.

Cellier M, Govoni G, Vidal S, Kwan T, Groulx N, Liu J, Sanchez F, Skamene E, Schurr E, Gros P 1994. Human natural resistanceassociated macrophage protein: cDNA cloning, chromosomal mapping, genomic organization, and tissue-specific expression. J Exp Med 180: 1741-1752.

Ferreira FR, Goulart LR, Silva HD, Goulart IM 2004. Susceptibility to leprosy may be conditioned by an interaction between the NRAMP1 promoter polymorphisms and the lepromin response. Int J Lepr Other Mycobact Dis 72: 457-467.

Fitness J, Floyd S, Warndorff DK, Sichali L, Mwaungulu L, Crampin AC, Fine PE, Hill AV 2004. Large-scale candidate gene study of leprosy susceptibility in the Karonga district of northern Malawi. Am J Trop Med Hyg 71: 330-340.

Graham AM, Dollinger MM, Howie SE, Harrison DJ 2000. Identification of novel alleles at a polymorphic microsatellite repeat region in the human NRAMPI gene promoter: analysis of allele frequencies in primary biliary cirrhosis. J Med Genet 37: 150-152.

Gruenheid S, Gros P 2000. Genetic susceptibility to intracellular infections: Nramp1, macrophage function, and divalent cations transport. Curr Opin Microbiol 3: 43-48.

Hatta M, Ratnawati, Tanaka M, Ito J, Shirakawa T, Kawabata M 2010. NRAMP1/SLC11A1 gene polymorphisms and host susceptibility to Mycobacterium tuberculosis and M. leprae in South Sulawesi, Indonesia. Southeast Asian J Trop Med Public Health 41: 386-394.

Kojima Y, Kinouchi Y, Takahashi S, Negoro K, Hiwatashi N, Shimosegawa T 2001. Inflammatory bowel disease is associated with a nov- el promoter polymorphism of natural resistance-associated macrophage protein 1 (NRAMPI) gene. Tissue Antigens 58: 379-384.

Li X, Yang Y, Zhou F, Zhang Y, Lu H, Jin Q, Gao L 2011. SLC11A1 (NRAMP1) polymorphisms and tuberculosis susceptibility: updated systematic review and meta-analysis. PLOS ONE 6: e15831.

Liu J, Fujiwara TM, Buu NT, Sánchez FO, Cellier M, Paradis AJ, Frappier D, Skamene E, Gros P, Morgan K, Schurr E 1995. Identification of polymorphisms and sequence variants in the human homologue of the mouse natural resistance-associated macrophage protein gene. Am J Hum Genet 56: 845-853.

Malo D, Vogan K, Vidal S, Hu J, Cellier M, Schurr E, Fuks A, Bumstead N, Morgan K, Gros P 1994. Haplotype mapping and sequence analysis of the mouse Nramp gene predict susceptibility to infection with intracellular parasites. Genomics 23: 51-61.

Meisner SJ, Mucklow S, Warner G, Sow SO, Lienhardt C, Hill AV 2001. Association of NRAMP1 polymorphism with leprosy type but not susceptibility to leprosy per se in west Africans. Am J Trop Med Hyg 65: 733-735.

Miller SA, Dykes DD, Polesky HF 1988. A simple salting out procedure for extracting DNA from human nucleated cells. Nucleic Acids Res 16: 1215.

Misch EA, Berrington WR, Vary Jr JC, Hawn TR 2010. Leprosy and the human genome. Microbiol Mol Biol Rev 74: 589-620.

Ridley DS, Jopling WH 1966. Classification of leprosy according to immunity. A five-group system. Int J Lepr Other Mycobact Dis 34: $255-273$

Roy S, Frodsham A, Saha B, Hazra SK, Mascie-Taylor CG, Hill AV 1999. Association of vitamin D receptor genotype with leprosy type. J Infect Dis 179: 187-191.

Searle S, Blackwell JM 1999. Evidence for a functional repeat polymorphism in the promoter of the human NRAMPI gene that correlates with autoimmune versus infectious disease susceptibility. J Med Genet 36: 295-299.

Singal DP, Li J, Zhu Y, Zhang G 2000. NRAMP1 gene polymorphisms in patients with rheumatoid arthritis. Tissue Antigens 55: 44-47.

Skamene E 1994. The Bcg gene story. Immunobiology 191: 451-460.

Soo SS, Villarreal-Ramos B, Khan CMA, Hormaeche CE, Blackwell JM 1998. Genetic control of immune response to recombinant antigens carried by an attenuated Salmonella typhimurium vaccine strain: Nrampl influences T-helper subset responses and protection against leishmanial challenge. Infect Immun 66: 1910-1917.

Teixeira MA, Silva NL, Ramos AL, Hatagima A, Magalhães V 2010. NRAMPI gene polymorphisms in individuals with leprosy reactions attended at two reference centers in Recife, northeastern Brazil. Rev Soc Bras Med Trop 43: 281-286.

Vejbaesya S, Mahaisavariya P, Luangtrakool P, Sermduangprateep C 2007. TNFa and NRAMP1 polymorphisms in leprosy. J Med Assoc Thai 90: 1188-1192.

Vidal SM, Malo D, Vogan K, Skamene E, Gros P 1993. Natural resistance to infection with intracellular parasites: isolation of a candidate for BCG. Cell 73: 469-485.

Vidal SM, Pinner E, Lepage P, Gauthier S, Gros P 1996. Natural resistance to intracellular infections: Nramp1 encodes a membrane phosphoglycoprotein absent in macrophages from susceptible (Nramp1 D169) mouse strains. J Immunol 157: 3559-3568.

Walker SL, Lockwood DN 2007. Leprosy. Clin Dermatol 25: 165-172.

Zaahl MG, Robson KJ, Warnich L, Kotze MJ 2004. Expression of the SLC11A1 (NRAMP1) 5'-(GT)n repeat: opposite effect in the presence of -237C-->T. Blood Cells Mol Dis 33: 45-50. 